\title{
Prevalence of Coccidiosis in Back Yard Chicken in and Around DebereTabere Town, South Gondar Zone, Amhara Regional State, Ethiopia
}

\author{
Temesigen W Molla*, Fentahun W Molla and Anuar Nuru \\ Department of Veterinary Medicine, University of Gondar, Ethiopia
}

*Corresponding author: Temesigen W Molla, Department of Veterinary Medicine,University of Gondar, Ethiopia

Submission: : July 26, 2017 ; Published: 毗July 12, 2018

\begin{abstract}
A cross sectional study was carried out to estimate the prevalence of chicken coccidial infections and assessment of the associated risk factor in backyard chickens in and around Debre Tabore town, South Gondar Zone, Northwest Ethiopia from October 2015 and May 2016.Floatation techniques were used for qualitative study of coccidialoocyst. Descriptive statistics was used to express prevalence while chi-square test used to assess if there was statistically significant association between targeted host factors and coccidial infection. The degrees of these associations were quantified using crude and adjusted odds ratio. Statistical significance was assumed if the confidence interval (CI) did not include one among its values or whenever p-value was less than $5 \%$. The overall animal prevalence for coccidial infections was $21.4 \%(48 / 224)$ and the prevalence was significantly associated with breed $(\mathrm{p}=0.019)$, age $(\mathrm{p}=0.028)$ and $\mathrm{sex}(\mathrm{p}=0.004)$ of the study animals. In a multivariable logistic regression analysis, female (Adjusted Odds Ratio $(\mathrm{AOR})=0.3 ; 95 \% \mathrm{CI}: 0.17-0.68)$ and exotic breeds (AOR=0.46; 95\% CI:0.23-0.93) were found less likely infected with coccidialoocystes as compared to male and local chickens. However, increased risk for coccidial infection was recorded in adult chicken (AOR=2.04; 95\%CI:1.02-4.08) as compared to the grower chickens. In conclusion, this study showed coccidial infection could be important in the backyard chickens in the study area even though the overall prevalence was relatively low. Moreover, the prevalence was higher in adults than the growers, which alerts the need to undertake suitable and practically applicable control and prevention measures in the parent stocks.
\end{abstract}

Keywords: Backyard chicken;Coccidian infection;Prevalence

Abbreviations: ASL: Above Sea Level; DVM: Doctor of Veterinary Medicine; FVM: Factuality of Veterinary Medicine; SPP: Species

\section{Introduction}

Poultry is now by far the largest livestock species in the worldwide (FAO, 2000), accounting for more than $30 \%$ of all animal protein consumption Permin \& Pedersen [1]. Poultry are the sole means of livelihood for the overall well-being of the household of the human being and provide a major income-generating activity from the sale of birds and eggs Jordan et al. [2] Coccidia are host specific Leite [3] and occur universally, most commonly in animals housed or confined in small areas contaminated with oocysts Radostitis et al. [4]. Climatic factors, age of the host and management determine the pattern of presentation of coccidiosis in different regions Acosta et al.[5]. Coccidiosis is one of the most important economically poultry diseases and coccidial infections are usually most common and important in chickens younger than 1 year Abebe et al.[6]. Coccidiosis is known to be the most prevalent and most expensive disease of poultry in the worldwide Gari et al. [7] It is one of the most alarming problems in poultry rearing industry and is responsible for morbidity and mortality Pandit [8].

Coccidiosis is an economically important disease in chicken caused by the Eimeria species Taylor et al. $[9,10]$. There are nine important species of Eimeria which appear to be distributed throughout the world Charlton [11], Conway \& Mckenzie [12]. Coccidiosis still continues to be one of the most expensive and common diseases of poultry inspite of advance made in prevention and control through chemotherapy, management, nutrition and genetic improvement Vegad [13].

The production of poultry protein has greatly expanded in many developing countries in the recent past. Nevertheless it has been adversely affected by variety of constraints, of which, poultry disease continues to play the major central role in hampering its development Jordan et al. [2], Safariet al. [14]. In Ethiopia ,poultry production is categorized in to traditional (backyard and freerange), small and large scale oriented sectors, which is based on the objective of the producer, the type of the input used ,the number and the type of chicken kept Alemu [15]. The rural poultry sectors constitute about $99 \%$ of the total chicken population and managed under the traditional village poultry production systems Tadell et al. [16]. Coccidiosis is endemic in Ethiopia and causing great economic losses in poultries in all production system (FAO.1995). 
Mathusela [17] and Safari et al. [14] had reported that coccidiosis contributes to $8.4 \%$ and $11.86 \%$ losses in profit in traditional poultry production system in Ethiopia, respectively. Losses due to mortality following severe outbreak may be devastating and incidence rates as high as $80 \%$ was also reported in another study conducted in Ethiopia Gari[7].

Despite several research have been undertaken in the area of poultry coccidiosis in different regions in Ethiopia Guale [18], Ashenafi [19], Mathusela [17], Lobago et al. [20], Safari et al. [14], Gari et al. [7] and Mersha et al. [21] the disease still a major problem in Amara Regional particularly in South Gondar Administrative Zone, and demanding much research and investigation. Therefore, the objectives of the present study were to estimate the prevalence of coccidial infections in backyard chickens in and around Debre Tabore Town and to identify risk factors associated with coccidial infection in the area.

\section{Materials and Methods}

\section{Study area}

The study was conducted in and in the vicinity of Debere Tabor Town from November 2015 and April2016.

\section{Study animals}

The study animals were backyard chickens from both sexes and different age groups. The majority was exotic breed chickens but small numbers of local breeds were used.

\section{Sample size estimation and sampling of the study animals}

The sample size was estimated using the formula indicated hereunder, which is used to estimate prevalence in a given population accordingly; a total of 224 chickens were calculated to be enough to estimate the prevalence by considering the expected prevalence of $17.7 \%$ with the precession of $5 \%$ and $95 \%$ confidence in the estimate. To recruit 224 chickens, volunteer households with chickens from Debre Tabor and the surrounding rural localities were registered and used as a sample frame. Simple random sampling technique was applied to select chickens from the available sample frame.

$$
\frac{N=1.96^{2}(p \exp )(1-p \exp )}{d^{2}}
$$

Where: N: Equired Sample Size; Pexp: Expected Prevalence; d: Absolute Precision

\section{Data collection}

Facal sample from each chicken was collected from plastic sheet placed under each chicken separately kept overnight with their leg tied against fixed stand using fiber strand. After gross examination, each fecal sample stored in a plastic universal bottle and immediately transported to Farta district Veterinary Clinical Laboratory for coprological examination. Each fecal sample were processed separately and examined for the presence of oocyst according. Briefly, $3 \mathrm{~g}$ of fecal sample was added in the beaker with $40 \mathrm{ml}$ flotation fluid. The mixture was strained through a metallic sieve in to test tube and placed test tube in test tube rack. Then after, the cover slips is placed atop the tube, making sure no air bubbles are present and allow to stand for 20 minutes. Eventually, the cover slip was removed, place on the slide and examined under the microscope starting with lower magnification power. On top of that animal related potential risk factors such as sex, age and breed were recorded when each fecal sample was collected.

\section{Data management and analysis}

The generated data was checked, coded and entered in to Microsoft excel work sheet and statistical analysis was made using STATA version 12 statistical software. Descriptive statistics like percentage was used to express prevalence while chi-square $(\chi 2)$ test used to assess if there was statistically significant association between target host factors and coccidial infection. The degrees of these associations were quantified using crude and adjusted odds ratio obtained from logistic regression models. Statistical significance was assumed if the confidence interval (CI) did not include one among its values or whenever p-value was less than $5 \%$.

\section{Result}

\section{General information on the study animals}

A total of 224 backyard chickens in and around Debre Tabore town were examined for coccidial infections with direct and floatation techniques. The sex of the majority of the study animals was female $(74.6 \% ; 167 / 224)$, the breed composition was exotic breed $(71.88 \%, 161 / 224)$ and local breed $(28.1 \%, 63 / 224)$.

\section{Animal prevalence and associated risk factors}

The overall individual animal prevalence for coccidial infections was $21.4 \%$ (48/224). The prevalence was significantly associated with selected host factors such as breed $(p=0.019)$, age $(p=0.028)$ and sex $(\mathrm{p}=0.004)$ of the study animals.

Results from bivariate and multivariable logistic regression analysis are summarized in (Table 1). After adjusting for the sex, breed and age, female and exotic chickens were found less likely to be positive for coccidial infections as compared male and local chickens. However, being adult as compared to young age was identified as a risk factor for coccidial infections.

Table 1: Bivariate and multivariable logistic regression analysis of coccidial infection in backyard chickens.

\begin{tabular}{|c|c|c|c|c|c|}
\hline Host Factor & Examined & Positive (\%) & COR (95\% CI) & A0R (95\% CI) \\
\hline \multicolumn{7}{|c|}{ Sex } \\
\hline Male & 57 & $20(35.1)$ & 1.0 & 0.004 \\
\hline Female & 167 & $28(16.8)$ & $0.37(0.19-0.73$ & $0.30(0.17-0.68)$ \\
\hline
\end{tabular}




\begin{tabular}{|c|c|c|c|c|c|}
\hline \multicolumn{7}{|c|}{ Breed } \\
\hline Local & 63 & $20(31.8)$ & 1.0 & 0.019 \\
\hline Exotic & 161 & $28(17.4)$ & $0.45(0.23-0.88)$ & $0.46(0.23-0.93)$ \\
\hline \multicolumn{7}{|c|}{ Age } & 1.0 \\
\hline Grower (2-8week) & 155 & $27(17.4)$ & 1.0 & $2.04(1.02-4.08)$ & 0.028 \\
\hline Adult(>8 week) & 69 & $21(30.4)$ & $2.071 .07-4.01$ & \\
\hline
\end{tabular}

Note: n: Number of Positive; COR: Crude Odds Ratio; AOR: Adjusted odds ratio; BCS: Body Condition Score; CI: Confidence Interval.

\section{Discussion}

The overall prevalence of coccidial infections in chickens in the present study was $21.4 \%$, which is comparable to the previously reported prevalence of $22.58 \%, 25.8 \%, 22.3 \%$ and $25.24 \%$ by other studies in different sites of Ethiopia Gari et al. [7], Ashenafi et al. [19], Alemayehu [22] and Amare [23] but significantly lower than the previously reported prevalence of $61.25 \%$ and $38.5 \%$ in Ethiopia Gariet al. [7], Netsanet [24] and 41.43\% in South Africa Mwale \& Masika [25]. However, the present finding was slightly higher than the previously reported prevalence of $11 \%$ reported in Central Ethiopia Lobago et al. [20]. The variation observed among the studies might be attributed to the sample size, epidemiology of coccidial infection in the comparison study sites, season of the year, agro ecology and differences in management systems of the chicken.

In the present study higher prevalence was recorded in adult chickens $(30.4 \%)$ than the growers (17.4\%). This finding disagrees with the reports of Ashenafi et al. [19] \& Gari et al. [7] who reported higher prevalence, in growers $(23.2 \%, 11.6 \%$, respectively) as compared to adult chickens $(35.3 \%, 22.3 \%$, respectively). Fgubb [26] and Jordan et al. [2] also indicated significantly higher prevalence of coccidiosis among naïve young chickens. The present finding also disagrees with the report of Julie [27], who stated that all ages of chickens are equally susceptible to coccidial infection. However, the higher infection rate recorded in adult chickens in the present study could be related to the unrestricted scavenging activities as compared to the younger chickens in the study area. Briefly, adult backyard birds are allowed to scavenge in village without any restriction and thus more likely to have access with sporulated oocyst in the contaminated environment. The growers in contrary separately supplemented with leftover cereal and other food items, as a result they spent most of their times in the vicinity of owners houses and less exposed to coccidial infections.

Although the background biological reason was not known, sex in the present study was significantly associated with coccidial infections. Being male sex was associated to the increased proportion of coccidial infection (35.1\%) as compared to female sex (16.7\%). This result is in agreement with the previous Ethiopian studies Garbi et al. [28], Alemayehu et al. [22] and Amare [23], although other finding did not report similar result PinardVL et al. [29].Analysis of breed in relation to coccidial infection in the present study was also found statistically significant $(p=0.019)$, and exotic breeds were found less likely to be infected (17.4\%) with coccidial infections as compared to local breeds of chickens (31.8\%). This finding disagrees with the report of Gari et al. [7] and higher prevalence was recorded in exotic breeds than the local breed. The difference could be attributed to the vaccination and prophylactic drugs given to the exotic chickens while they were purchased and/or distributed from the local agricultural office or commercial poultry farms [30].

\section{Conclusion}

Even though relatively low, this study showed coccidial infection [31] could be important in the backyard chickens in the study area [32,33]. Significant associations were recorded between the occurrence of coccidial infections in chickens [34-36] and selected host factors such as sex, breed and age. Being female and exotic breed were found protective host factors as compared to their comparative factors such as being male and local breed [37-42]. However, being adult chicken was identified as animal level risk factor for being infected with coccidial infections [4348]. Based on the above findings the following are forwarded as recommendations:

\section{Recommendations}

A. Adult and local chicken focused prevention and control strategy should be designed and executed to control and prevent coccidiosis in backyard chickens in the study area [49].

B. Chicken owners in the study area should be educated and aware on the proper management techniques [50-53].

Further studies are forwarded to identify the type of Eimeria species that are causing coccidiosis in backyard chicken in the study area [54].

\section{References}

1. Permin A, Pedersen G (2000) Problems related to poultry production at village level: possibilities, proceedings of smallholder poultry projects in Eastern and Southern Africa, Southern Africa, pp. 65-69.

2. Jordan F, Pattison M, Alexander D, Faraher T (2002) Parasitic disease poultry diseases ( $5^{\text {th }}$ edn), WB Saunders, China, pp. 405-450.

3. Leite ML (2009) Coccidiosis in goat and perevention. Alabama Cooperative Extension System UNP 109, USA, pp. 1-3.

4. Radiostitis OM, Gay C, Constable PD, Hinchliff KW (2007) Disease associated with protozoa, veterinary medicine a text book of the disease of horse, sheep, pig, and goat. Harcourt publishers Ltd $\left(10^{\text {th }}\right.$ edn), London, pp. 1498-1506. 
5. Acosta JF, Alpizar JL, Vivas RI (1996) Epidemiological factors associated to poultry coccidiosis in chicken in a subhumid tropical climate. Rev Biomed 7(4): 211-218.

6. Abebe W, Rahmeto A, Bersissa K (2008) Epidemiology of Eimeria infections in chicken in Addis Ababa and Debre Zeit poultry farms, Ethiopia. Intern J Appl Res Vet Med 6(1): 24-30.

7. Gari G, Tilahun G, Dorchies Ph (2008) Study on poultry coccidiosis in Tiyo District, Arsi zone oromia regional state, Ethiopia. Intern J Poul Sci $7(3):$ 251-256.

8. Pandit BA (2009) Prevalence of coccidiosis in poultry in kashmir vally. Vet Scan 4(1): 16-20

9. Taylor MA, Coop RL, Wall RL (2007) Veterinary parasitology. Black well published ltd ( $3^{\text {rd }}$ edn), Singapore, pp. 39-73.

10. Taylor MA, Coop RL, Wall RL (2007) Veterinary parasitology. Black well. Science $\left(3^{\text {rd }}\right.$ edn), UK, pp. 475-484.

11. Charlton BR (2006) Coccidiosis. In: Avian disease manual. International Book distrusting company in association with American association of avian pathologist ( $5^{\text {th }}$ edn), USA, pp. 153-156.

12. Conway Dp, Mckenzie (2007) Poultry coccidiosis, Diagnosting and testing procedures. Blackwell publishing ( $3^{\text {rd }}$ edn), USA.

13. Vegad JL (2004) Poultry coccidiosis. In: poultry diseases, a gaide for farmers and and poultry professionals. International Book Distributing Company, India, pp. 186-197.

14. Safari M, Kinung H, Getachew T, Hafez W, Moges K, et al. (2004) Assessment of economic impact caused by poultry in small and large scale farm in DebreZeit, Ethiopia. International Journal of science 3(11): 715-718.

15. Alemu Y (1995) Poultry production in Ethiopia. World Poultry Science Journal 51(2): 197-201.

16. Tadelle D, Million T, Alemu Y, peters KJ (2003) Village chicken production system in Ethiopia: use patterns and performance evaluation and chicken products and socioeconomic functions of chicken. DebreZeit Agricultural Research center, Debre Zeit, Ethiopia. Livestock Research for Rural Development 15(1).

17. Mathusala S (2001) Studies on prevalence and Economic impact of poultry coccidiosis in different production system in DebreZeit and Addis Abeba Ethiopia. MSc thesis. Faculty of Veterinary Medicine. Freie Universty of Berlin Debre Zeit, Germany.

18. Guale F (1990) Poultry coccidiosis and effect of management system: An assessment Trial in Debre Zeite and its surrounding. DVM thesis, Faculty Veterinary Medicine, Addis Abebe University, Debre Zeit, Ethiopia.

19. Ashenafi H, Tadess S, Medhin G, Tibbo (2004) Study on coccidiosis of scavenging indigenous chicken in the central Ethiopia. Tropical Animal Health production 36(7): 693-701

20. Lobago J, Nigussie D, Wossene A, Ashenafi H (2003) The study on major diseases of chickens in Debre Zeit, Centrale Ethiopia. Bulletine Animal Health Production 51:11-21.

21. Mersha C, Negash T, Samuel BT (2009) Occurrence of concurrent infections disease in broiler chickens is treat ti commurical poultry farms in central Ethiopia. Tropical Animal Health and Production.

22. Alemayehu T, Tekeselassie A, Kassa SA (2012) Prevalence study of poultry coccidosis in small and large scale farms in Adis Ababa, Ethiopia. Scientific Journal of Crop Science 1(1): 26-30.

23. Amare A, Worku W, Negussie H (2012) Coccidiosis prevailing in parent stocks: A comparative study between growers and adult layers in kombolcha poultry breeding and multiplication center, Ethiopia. Global Veterinaria 8(3): 285-291.

24. Netsanet W (2003) Poultry coccidiosis: its prevalence and distribution of
Eimeria species in kombolcha, South Wollo, Ethiopia. DVM thesis Faculty of Veterinary Medicine, Addis Ababa University, Debreziet, Ethiopia.

25. Mwale M, Masika P (2011) Point prevalence study of gastro-intestinal parasites in village chickens of Centane district, South Africa. Afr J Agri Res 6(9): 2033-2038.

26. Fgubb VK (1992) Pathology of domestic animals $\left(4^{\text {th }}\right.$ edn), Tornto San Giego, New York, USA, p. 297.

27. Julie DH (1999) Coccidiosis in poultry livestock, Poultry Health Programs, Clemson, Columbia 17: 191-199.

28. Garbi F, Tesfaye A, Woyessa M (2015) Study on the prevalence of poultry coccidiosis in Nekemte town, East wollega, Ethiopia. African Journal of Agriculture Research 10(5): 328-333.

29. Pinard Van Der Laan MH, Monvoison J, pery P, Hamet N, Thomas M(1998) Comparsion of bred Line of chickens for resistence to expermental infection with coccdoiosis (Eimeria tenella ). Poultry Science 77(2): 185-191.

30. Bowman D (2009) Georges parasitology for veterinarians. Saunders Elsevier ( $9^{\text {th }}$ edn), India, pp. 02-94.

31. Bowman D Geogis D (2003) Parasitology for veterinarian. Saunder $\left(8^{\text {th }}\right.$ edn), USA, p.91.

32. Central Statistical Authority (CSA) Federal Democratic Republic of Ethiopia, Central Statistical Authority (CSA), Agricultural Sample Survey Coccidiosis in chicken.

33. Dubey JP, Wouda W, Muskens J (2008) Fatal intestinal coccidiosis in a three week old buffalo calf (Bubalus bubalus). American Society of Parasitologists 94 (6): 1289-1294.

34. Etuk B, Okoli C, Uko M (2004) Prevalence and management issues associated with poultry coccidiosis in Abak, Nigeria. Intern J Poult Sci 3(2): 135-139.

35. Fanatico A (2006) Parasate management for Natural and Organic poultry coccidiosis

36. (1995) Live stock development strategy for low income countries. In: Proceedings of the joint ILRI/FAO round table on the livestock development strategies for low income countries, (ILRI/FAO) Addis Abeba, Ethiopia, pp. 9-22.

37. Fitzpatrick S (2006) Coccidiosis in poultry. Agnote, regional veterinary officer, Katherine. NO. K26, pp. 1-3.

38. Foreyt Jw, (2001) Veterinary parasaitology Referance Manual. Black Well $\left(5^{\text {th }}\right.$ edn), USA, p. 155.

39. Hansen J, Perry B (1994) The epidemiology, diagnosis and control of helminthes parasites of small ruminants: A hand book. ILRAD, Nairobi, Kenya, pp. 57-72.

40. Hendrix CM (1998) Diagnostic veterinary parasitology. ( $2^{\text {nd }}$ edn), Alabama: Auburn University, USA, pp.15-27.

41. Kaufman J (1996) Parasitic infection of domestic animals, a diagnostic manual. Birkhauservelag, Germany, pp. 24-27.

42. Kennedy MJ (2011) Coccidiosis in poultry. Government of Alberta agricultural and rural development 2: 1-4.

43. Kenney MJ (2001) Coccidiosis in poultry. Government of Alberta agricultural and rural development 16:1-2.

44. Kirkpatrick JG, Selk G (2011) Coccidiosis in poultry Division of Agricultural Sciences and Natural Resources, Oklahoma State University VTMD-9129, pp. 1-2.

45. Lassen B (2009) Diagnosis epidemiology and control of poultry coccidiosis in Estonia. Institute of Veterinary Medicine and Animal Sciences, Estonian University of Life Sciences, pp. 1-156. 
46. Maas J (2007) Coccidiosis in poultry. UCD vets views California cattlemen's magazine, pp. 1-2.

47. Nematollahi A, Gholamali M and Reze FP (2009) Prevalence of Eimeria species among broiler chicks in Tabriz, Iran. Munis Entomol and Zool 4(1): 53-58.

48. Pence M (2011) Coccidiosis in poultry. University of Georgia, Collage of veterinary medicine, pp.1-3.

49. Perfield K (2010) Coccidiosis in dairy calves and heifers. Elanco Animal Health, pp.1-2.

50. Quigley J (2001) A Review of coccidiosis in poultry. Chicken notes Com17: 1-6.
51. Schipper IA (2000) Lecture out line of preventive veterinary medicine for animal science student. sujeet publication $\left(6^{\text {th }}\right.$ edn $)$, India, pp. 322324.

52. Scott P (2011) Coccidiosis in poultry. East of England Development Agency, pp. 1-2.

53. Stokka GL (1996) Coccidiosis: extension beef cattle veterinarian department of animal science and industry. Kansas state university, Agricultural Experiment Station and Cooperative Extension Service 2209, pp. 1-2.

54. Thrusfield M (2007) Veterinary epidemiology. Blackwell Science $\left(3^{\text {rd }}\right.$ edn) London, pp. 222-234.
Creative Commons Attribution 4.0 International License

For possible submissions Click Here

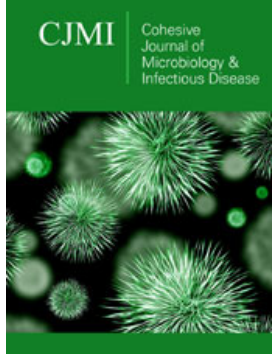

Cohesive Journal of Microbiology \& Infectious Disease

\section{Benefits of Publishing with us}

- High-level peer review and editorial services

- Freely accessible online immediately upon publication

- Authors retain the copyright to their work

- Licensing it under a Creative Commons license

- Visibility through different online platforms 